\title{
Under the Pagoda Mountain: Japanese POW Reformation During the Anti-Japanese War
}

\author{
LI Jin \\ University of Macau, Zhuhai, China
}

\begin{abstract}
As a typical Lenin-style political party, what should be concerned most is the CPC's (Communist Party of China) capacity in fighting against and clearing enemies. This study provides a distinct perspective to observe and recognize CPC's ability of turning hostility into friendship. Japanese prisoners of war (POW) had been poisoned by ultra-nationalism and militarism for years, and thus were extremely difficult to be reformed. However, under the correct ideological guidance of Mao and the unremitting efforts of the CPC's political officers and cadres, a great number of them acknowledged the CPC's political ideology and joined the CPC's team.
\end{abstract}

Keywords: Anti-Japanese War, prisoner of war, political transformation

\section{Previous Studies on the Subject}

A series of Japanese prisoners of war (POWs) and Japanese who had been indoctrinated and led by the Communist Party of China (CPC) and guided by the Communist Party of Japan, published their memoirs and reminiscences since 1960s. A book named The Story of Anti-War Soldiers: The Record of Members of Japanese Anti-War Alliances in China (Nihon Kyosanto, Chuoiinkai Hansen, Domei Kiroku \& Henshu Iinkai, 1963; 1987), which recorded Yoshidumi Kiyoshi, Mizuno Yasuo, Akiyama Yoshiteru, Kagawa Masao, and others' experience of being captured, indoctrinated at the Japanese Worker and Peasant School and participating in the anti-war campaign, was edited and published by the Central Committee of the CPC in 1963 and published by the Chinese Cultural and Historical Press with the name: Transition From an Imperial Soldier to an Anti-war Warrior in 1986. Both Akiyama Yoshiteru and Mizuno Yasuo made a comparison between their diehard attitude at the early period of being captured and their repentance of crimes after being indoctrinated. They also described in detail their experience of fighting and living in the Eighth Route Army in their memoirs-The Anti-War Soldiers: The Records of War and Life (Akiyama, 1978; Mizuno, 1974) respectively.

Maeda Mitsushige, one of the leaders of the Japanese People's Anti-war Alliance, published (in its original language) 八路軍の日本兵たち一延安日本労農學校の記録, co-authored with Kagawa Takashi in 1984. The book focused on their psychological changes before and after being captured, and their state of life in Japanese Worker and Peasant School in Yan'an. This book specifically described the situation of fighting against Japanese aggressors side by side with Chinese people. The book was translated by Zhao Anbo and $\mathrm{Wu}$ Congyong, who participated in the process of indoctrination and the process of forging friendship between the two countries in the postwar era. The translators named it The Japanese Soldiers in the Eighth Route Army (Kagawa \& Maeda, 1984; 1985), and it was published by People's Liberation Army (PLA) of China Publishing

LI Jin, Ph.D., Department of History, University of Macau, Zhuhai, China. 
Press two years after the original work's publishment. Professor Suzuki Denzaburo (鈴木伝三郎) at the National North China School of Administration was captured by the Eighth Route Army and escorted to Yan'an in the process of transferring his family members in 1945. As a senior intellectual, he made a complete account of the political situation of and daily life in the Anti-Japan Bases he saw with his own eyes, especially the impression of the indoctrinating personnel and senior leaders of the CPC. He also described his psychological transformation from "taking an antagonistic attitude towards and being indifferent to the CPC" to "further understand the CPC, show sympathy to the CPC and treat the CPC in a friendly manner". The book was compiled and published by the Saimaru Shuppankai (a publishing house) in 1983. Liu Guolin, who served in the Department of Work on adversaries of the Eighth Route Army at that time and a participant of the indoctrination process of Suzuki Denzaburo, translated the book. By combining some related memoirs written by Liu himself, the book: Memoir of a Former Member of the Eighth Route Army and a Japanese Prisoner of War (Suzuki \& Liu, 2000) was published. It is of great historical value to describe the common memories of a war from two different perspectives.

I Was a Young Soldier of the Eighth Route Army written by Yamaguchi Mitsufumi (山口盈文) (1994) and Under the Red Star: 8-Year Record of an Medical Officer of the People's Liberation Army written by Imamura Kyohei (今村匡平) (1967) were described in detail and typical. Yamaguchi Mitsufumi described his related experience. He came to the Northeast China as a member of "the Expansion League of Manchuria and Mongolia", and was then captured as a reserve soldier of the Kwantung Army. After witnessing all sorts of miseries in the house of detention under the jurisdiction of the Soviet Army, he decided to run away, and occasionally joined the PLA. He fought a great number of battles at different places, and finally finished his service in Hainan Island Campaign. While he followed the PLA, his belief was gradually changed, switching to Marxism. Imamura Kyohei graduated from Manchuria Medical University. He was captured by the Soviet Army as a military medical officer of the Kwantung Army, and was then handed over to the CPC and enlisted into the PLA for his excellent professional skills. He joined it for surviving purpose at first, but later he began to understand and accept the idea advocated by the CPC, which gradually enabled him to clear his old mentality away and transform from believing in the idea of "dedication to the Emperor" to devoting himself to the liberation of the ordinary people and creating happiness for the general public. In addition, in Akiyama Yoshiteru's (秋山良照) (1977) book: Experience of National Land Reform in China, the author detailedly described his participation of the Land Reform Movement in Guangdong Province following the PLA. He experienced the political difficulties of the People's Republic of China at its initial period, and compared it as the inevitable labor pains of a mother when she was giving birth to a new baby.

The Chinese researchers also concentrated on the efforts and results of the propaganda policy and re-education program of the CPC. Most of them praised the effectiveness of the policy and the program and believed they made great contribution to the development of democratic movement and communist activities in Japan after the War. However, most research failed to reveal the true reason of the transformation of Japanese POWs, since they ignored exploring the feelings and thoughts of Japanese POWs and only relied on the words and papers published by the CPC (Jia, 2001; Bao, 2007).

In addition, almost all previous studies were conducted only on Japanese POWs or war criminals during a same period of time, whereas no study undertook a comprehensive and continuous study on the transformation of POWs, immigrants, and war criminals at three different stages: the War of Resistance against Japan, the Civil War, and the founding of the PRC. Since Japanese POWs, immigrants, and war criminals in these three 
periods have experienced long-term ultra-nationalism and militarism, their political ideology was not much different. In terms of receiving the re-education program of the CPC, their psychological changes could be generally divided into three phases: the resistance stage, the acquiesce stage, and the converted stage. This ideological-to-behavioral connection cannot be reflected in the study of a single group in a single period, and is undoubtedly the weak point of past research.

With the help of the news report at that time, the memoirs related to the CPC's cadres and Japanese war criminals that are recognized as the subject and object of the POW policy of the Party, are worth investigating. It is a great opportunity to check if these Japanese POWs were truly transformed during the war and how did he change himself from a faithful warrior of the Japanese Emperor to the advocate of Marxism.

\section{Theoretical Basis of CPC on the POW Issue}

The ideological reforms of Japanese POW are subordinate to the so-called "work on adversaries" of the CPC. The ideological foundation of this work was Marxist Internationalism during the War of Resistance against Japan. The origin of Internationalism came from the free-trade thoughts prevailing in the first half of the 19th century. However, after Marx's theoretical system of scientific socialism gradually dominated the development of the Leftist Theory, Internationalism was absorbed into the theoretical framework of Marxism. By incorporating the class theory and global revolutionary theory in Marxism, Internationalism was later developed as "Marxist Internationalism" or also known as "Proletarian Internationalism".

Marx believed that, with the continuous expansion of capitalism in the world, "all domestic production and consumption shall be global. Consequently, the one-sidedness and limitation of a nation will be increasingly impossible" (Marx \& Engels, 1848). Because of the same class attributes, proletariats in the globe have the common interests and struggle goals. With the success of the proletarian movement in the world and the disappearance of class antagonism in a nation, the hostile relations among nations will finally disappear. According to this ideological principle, the proletariat of different countries had successively formed the First, the Second, and the Third International. It also guided the proletariats of a country to support the anti-fascist struggle in another country regardless of the territorial and the national boundaries during the Spanish Civil War and the Second World War. The Marxist Internationalism became an important part of Marx's theoretical system.

However, there is an inevitable contradiction for the proletarian organizations under the guidance of Marxism Internationalism. This is because Marxism Internationalism is based on the highly developed capitalism. The First International (1864-1876) was the earliest practice of proletarian internationalism theory. It was formed by workers' organizations in two highly capitalist countries-Britain and France. But even the capitalist system in such two developed capitalist countries was far from mature to narrow the gaps between oppositional classes within a nation. It was impossible to eliminate all hostile relations and create the great integration of the proletariat all over the world. This was particularly true for China during the War of Resistance against Japan, where national consciousness was still incomplete, and huge invasion threat from Japan was becoming increasingly fierce. It was high time to promote nationalism vigorously in order to strengthen the cohesion of the nation, as well as to unite all forces that could be united in order to resist external invasion and expel the aggressors. Thus, the need for promoting nationalism in response to a war of aggression was directly contradicted with Proletarian Internationalism. 
The contradiction between revolutionary ideals and the reality of war was also reflected in the CPC's political choices and military tactics during the War of Resistance against Japan. On the one hand, confronting powerful external enemy, the CPC was supposed to devote all strength to the war to ensure the victory and the survival of the nation. On the other hand, the CPC must preserve its forces and seek survival and development in order to maintain the revolutionary ideals. According to Gao Hua's research, the different opinion on the prioritization of the above two aspects was the core contradiction between "Maoist Faction" led by Mao Zedong and the "Internationalist Faction" headed by Wang Ming (who came back from Moscow and represented the will of the Communist International). Wang asked the CPC to abandon the struggle for the leadership of National War, and give it to Chiang Kai-shek and the Nationalist government. This strategy was aimed at reducing the possibility of the Soviet Union being attacked on both sides by Germany and Japan. In other words, "Internationalist" hoped to strengthen cooperation with the KMT and Chiang Kai-shek, form a national united-front, and invested most strength to resist Japanese aggressors via extensive mobile warfare and supplemented with guerrilla warfare.

Maoists agreed that the national conflict between China and Japan was the principal contradiction while the class contradiction held the secondary place during the period of the War of Resistance against Japan. However, they also maintained that the necessity of struggles for class and leadership should not be overlooked. The Party should adhere to the principle of independence while forming the united anti-Japanese national front with the KMT. In terms of military strategy, the CPC preferred taking guerrilla warfare as the primary struggle form. While fighting against the aggressors, the CPC should pay attention to the preservation and development of its own strength. This internal conflict was eventually ended with Maoists' victory. After obtaining the forgiveness of the Communist International, Maoists criticized Wang Ming's "right-deviationist mistake" at the Sixth Plenary Session of the Sixth Party Congress held from September 29 to November 6, 1938. The meeting dissolved the Changjiang Bureau of the CPC Central Committee, which was chaired by Wang Ming, and thus consolidating Mao Zedong's leadership in the Communist Party of China (Gao, 2000).

After the brief turmoil caused by Internationalists, the CPC's political and military strategies were reunified under Mao Zedong's ideological system. The dual-publicity strategy was adopted by the CPC in order to resolve the contradiction mentioned above. In terms of consolidating and developing "the National Anti-Japanese United Front", the CPC carried out the propaganda strategy based on nationalism in the KMT-ruled areas, while the policy targeting Japanese soldiers and prisoners was based on Marxist Internationalism. Such dual-publicity strategy solved the contradiction between the realistic warfare and revolutionary ideals mentioned above. Moreover, such strategy benefited the CPC in two aspects. On the one hand, this strategy attracted sympathy and support from anti-Japanese factions of the KMT, as well as a large number of young intellectuals from the KMT-ruled areas who were unsatisfied with the KMT's ruling. It further led to overwhelming public and political pressure on Chiang Kai-shek and the KMT government, which not only prevented the KMT from making peace with Japan separately, but also avoided the situation that CPC might be in war with Japan and the KMT on both sides. On the other hand, this strategy improved the success rate and efficiency of ideological transformation towards POWs, which not only brought valuable allies in propaganda work and psychological warfare against the Japanese army, but also cultivated necessary personnel for a "Red Japan" in the future envisaged by the CPC.

In October 1937, when interviewed by the British journalist James Bertram, Mao Zedong proposed his own views on the work on adversaries of the CPC and the Eighth Route Army: 
1. The real opponents of Chinese people were the headquarter of Japanese army, as well as the warlords and plutocrats who waged the war of aggression. Ordinary Japanese people were forced to leave their families and trudge to China, shedding innocent blood for the ambition of a small amount of people. To some extent, the common Japanese soldiers were also the victims of war, just like Chinese people. Therefore, they should join hands with Chinese people to confront the common enemy: Japanese imperialists. "Even if they are sent to China to fight against us, Japanese people and the colonial people oppressed by Japan have no real conflicts with us. They are not our enemies but friends".

2. Based on the outlook of Marxist Internationalism, the CPC followed its POW policy in Agrarian Revolution on the new battlefield. It was necessary to treat POW favorably and likewise pay attention to propaganda and win POW's support. "Captives will be disarmed, but they shall not be insulted or abused in any case. They will be released after being explained the common interests of Chinese people and Japanese people". "Captives who are reluctant to rejoin their original troops can serve in the Eighth Route Army. If international brigades joined the War of Resistance against Japan in the future, they can participate in and take up weapons to fight against Japanese imperialism".

3. Mao Zedong also believed that different attitudes should be held towards POWs based on their class status, and specific policies of POWs should be formulated accordingly. "Ordinary soldiers and oppressed people, especially Inner Mongolians and Manchus who are compelled by the Japanese imperialists to fight against us will be treated as our friends and comrades. Anyone who would like to join us in opposing Japanese imperialism is extremely welcomed by our army, while those who are unwilling to be with us shall have freedom to return to his troops. Japanese officers will share the same policy".

Mao deemed that there were even opportunities for senior Japanese officers who were accountable for the war to be saved and transformed. "However, we will detain the officers who command Japanese people to invade China or support existing policies made by Japanese warlords for some time, so that they can realize the mistakes they made. If they make confessions, we will release them as well".

4. Bertram questioned whether the CPC's policy about releasing POWs would result in tactical loss because Japanese army may abuse the Japanese POWs released by the CPC. Mao suggested that the CPC adhere firmly to Internationalism and class viewpoint when carrying out work on adversaries, regardless of the atrocities committed by Japanese army. "The more released prisoners they kill, the more Japanese soldiers will sympathize with China". "Although Japanese commanders have declared that Japan may use poisoned gas on the Eighth Route Army, we will not change the policy of preferential treatment towards POWs" (Bertram, 1986, pp. 126-127).

Regarding the goals and possible outcomes of the work on adversaries, Mao Zedong stated in his famous article: “On the Protracted War" (論持久戰) that “the aggressive war initiated by Japanese governors is doomed to fail and it will be likely to trigger people's revolution in Japan. The day when Japanese people win the victory of revolution will be the time of Japan's transformation" (Mao, 1991, p. 457). The above statement expounded how the CPC understood and carried forward Marx's theoretical system: to formulate corresponding against-enemy policies by combining practical problems brought by the War of Resistance against Japan. It can be recognized as a meaningful attempt of localizing Marxism in China. The POW policy adopted in the War of Resistance against Japan was implemented on the basis of Mao Zedong Thought. Even in 1952, when the Party has fully possessed the political power of China and needed to deal with a group of Japanese war criminals that were primarily made up of senior Japanese officers and former Manchukuo 
officials, the CPC continued to carry out the same policy on the basis: "re-education, transformation, and release after confession". This strategy was put forward by Mao Zedong at the time of talking to James Bertram in a cave of Yan'an 15 years ago.

\section{Specific Practices of the Exploration Period}

Specific practices of the CPC's work on adversaries could be divided into two periods. The first period, from1937 (when CPC fully took part in the War of Resistance against Japan) to 1940, could be regarded as the exploration period. During this period of time, specific strategies mainly followed the policy of propaganda and transformation towards the KMT soldiers in Agrarian Revolution. However, because the effectiveness was far from expectation, the CPC began to re-evaluate its propaganda tactics and integrated its own experience about the new form of national war. Consequently, the CPC strengthened the participation rate of re-educated Japanese anti-war activists in its work on adversaries. The second period started from 1940 when the leader of the Japanese Communist Party (JCP): Nosaka Sanzo (野阪參三), arrived in Yan'an and got involved in the work on adversaries of CPC, and ended by the end of the War in 1945. The participation of a large number of Japanese POWs, who were extremely familiar with the cultural background, psychological state, and combat condition of Japanese army, enabled CPC to gradually develop an anti-war propaganda strategy that fitted the psychological requirements of the Japanese army, as well as a comprehensive POW management system that allowed the Marxist theory to be effectively instilled to the engaged POWs in the War of Resistance against Japan. It also laid a solid foundation for the future creation of a "Red Japan". This stage could be defined as the maturity period of the CPC's work on adversaries.

The Declaration of the CPC to Japan's Army, Navy and Air Forces (中國共產黨告日本陸海空軍士兵宣 言) and The Eighth Routes Army Addressing to Japanese Soldiers (八路軍告日本士兵書) were issued on September 25, 1937 in the name of the CPC and the Eighth Route Army respectively. They elaborated the CPC's aforementioned understanding of the national war and called on Japanese soldiers to recognize their true enemies and turn against to the true oppressors and exploiters of Japanese people: the Japanese army headquarter. At the same time, it formally stated the CPC' attitude towards Japanese POWs and survivors, that

in the battle, we will never kill someone who is willing to be disarmed. Anyone with the inclination to serve in our army will be warmly welcomed while those with disinclination will be released and are free to rejoin his troops once demilitarized. We will never slaughter a Japanese soldier who is not armed or disarmed! (Literature Research Office of the Central Committee of the Communist Party of China, 1991, p. 357)

According to the past experience in propaganda against the KMT army in Agrarian Revolution, the CPC forecasted optimistic achievements on remolding Japanese soldiers, and some cadres were even convinced that "to capture one to two thousand Japanese for future propaganda in one battle" was out of problem (Cai, 1938, p. 220; Yang, 2013, p. 19). However, front-line officers and grass-root political workers of the CPC massively underestimated the intractability of the Japanese army, which was exposed thoroughly on the battlefield. In the Battle of Pingxingguan, the first battle for the two armies to confront each other directly, non-combat depletion of soldiers frequently happened due to the capture of Japanese soldiers. For example, some Japanese soldiers pretended to be dead, waiting to kill the Chinese soldiers who were preparing the stretcher for him; a Japanese soldier bit an ear of a battalion commander of the Eighth Route Army who was carrying him to the rescue. There was even an incident that a wounded Japanese soldier killed a doctor of the Eighth Route Army who was changing dressing for him. When interviewed by Bertram, Zhou Enlai and Zhu De also indicated that the strict 
discipline and stubborn ideology of the Japanese army, as well as the language barrier, made it extremely difficult to capture Japanese soldiers alive. "Our soldiers do not speak Japanese, so we could hardly verbalize our thoughts to those who refused to surrender, thus making us fall into a passive situation. Then, great efforts have been made to interpret our policy to Japanese POWs" (Bertram, 1986, p. 168).

During the Agrarian Revolution, the number of POWs was generally equal to or even several times larger than the death toll of the KMT troops in a medium-sized battle like the Battle of Pingxingguan. However, in this exact battle, the CPC killed more than a thousand Japanese soldiers, but only captured less than 10 captives. It was recognized as a setback of the CPC' work on adversaries in the initial period of the War of Resistance against Japan. The experience reminded the political cadres of the Eighth Route Army that although Japanese low rank officers were mainly the oppressed class, such as workers and peasants who were forced to fight against China by Japanese governors, the stubbornness and brutality demonstrated by Japanese soldiers in the fight could not be explained simply as "they were obsessed, deceived and coerced by the emperor of Japan and its army". More profound reasons should be explored.

Based on the vivid experience gained from blood-shedding battlefields, the CPC, based on the same theoretical basis, has begun to adjust some specific strategies for work on adversaries. Political Department of the Eighth Route Army enacted the Instruction on Carrying out Political Work Against the Japanese Army by Political Department of the Eighth Route Army (八路軍政治部關於開展日軍政治工作的指示) on October 6, 1937, shortly after the Battle of Pingxingguan. Compared with the Declaration of CPC's Report to Japan's Army, Navy and Air Forces (中國共產黨告日本陸海空軍士兵宣言) and The Eighth Route Army Addressing to Japanese Soldiers (八路軍告日本士兵書) published just 10 days before, this Instruction targeted at soldiers and cadres of the Party and re-emphasized the importance of work on adversaries in the new war. It raised a specific policy towards POWs based on the characteristics of Japanese army. "POWs and the wounded Japanese soldiers should be given preferential treatment and medical treatment respectively, while soldiers who resolutely refuse to surrender on the battlefield should not be killed. However, those disarmed POWs should be brought back in multiple ways to carry out political propaganda and re-disposal rather than simple infliction". It also proposed several central tasks for the next phase of work on adversaries, including organizing frontline soldiers and propagandists to learn Japanese, training and enriching cadres responsibility for the work on adversaries, preparing publicity materials in Japanese after collecting relevant intelligence, pasting the printed versions in enemy-occupied areas and traffic lines, and strengthening research and liaison between the departments of work on adversaries (such as report and share the experience of work on adversaries in a timely manner). In addition, this document also pointed out a vital reason why Japanese soldiers did not surrender in desperation but put up a strong resistance: They believed that, in history, Chinese troops not only had no specific work on adversaries politically, but also took brutal measures to treat POWs in the past (Editorial Team of Historical Materials of the Chinese People's Liberation Army, 1994a, p. 61). It was remarkable for the CPC to introspect its own historical problems instead of simply accusing the brutality and stupidity of enemies.

In addition to announcing a clear policy of POW, the CPC also organized its soldiers to quickly learn some slogans in Japanese, such as "no killing of Japanese POWs", "favorable treatment to Japanese POWs", and "medical treatment to wounded Japanese soldiers". In the Battle of Guangyang in October 1937, when only a few commanders and officers were fluent in these slogans, a number of Japanese soldiers were successfully captured alive (Luo, 1988, p. 182). 
After the fall of Taiyuan in November 1937, the large-scale battles between the KMT army and Japanese army in North China were temporarily suspended. The guerrilla warfare led by the CPC and the "defensive warfare" of the Japanese garrison army stationed in the north became the two main forms of the War of Resistance against Japan in North China. The CPC's armed forces infiltrated deeply into Japan-ruled areas in North China to carry out large-scale and long-term guerrilla warfares. In 1938, the Eighth Route Army successively set up a number of anti-Japanese bases in different areas, including Shanxi-Chahar-Hebei, Northwest Shanxi and Daqing Mountain, Shanxi-Hebei-Henan, Southwest Shanxi and Shandong. The Eighth Route Army repeatedly battled with the Japanese garrison army stationed in North China for the control over a certain area. The battle lines between the two sides were intertwined with the unbalanced power distribution.

The key to win the war was not only to fight the enemy, but also divide and disintegrate the enemy. Compared with the large-scale battles in the former stage, the battles at this stage were mainly long-term seesaw wars and attribution wars, in which appropriate propaganda and psychological strategies would be effective. Therefore, the CPC expanded its propaganda and psychological infiltrations in daily operations, increased the input in work on adversaries, and lowered its expectations.

According to the current situation of the Japanese army, we should not overestimate the working policies and immediate goals of Japanese army. We should not pin our hope on establishing a united front with transformed Japanese troops against the aggression of the Japanese army, or building an anti-war fortress in the Japanese army, or a mutiny of a large number of Japanese soldiers that would join in Chinese troops. These ambitious goals are far from possible or practical in the current stage, and we should continue our efforts in achieving them. (Editorial Team of Historical Materials of the Chinese People's Liberation Army, 1994b, p. 388)

Meanwhile, the CPC altered its previous propaganda tactics which were based on the class viewpoint and other ideological theories of Marxism. The new propaganda strategy paid close attention to guide, stimulate, and inspire the anti-war sentiment of Japanese soldiers.

Today's policy to the Japanese army should be: weakening and reducing the combat effectiveness of Japanese soldiers in various ways, so that Japanese soldiers would not blindly hate the Chinese army and civilians, and gradually cultivating political closeness via emotional approaches. Thus, promotional materials should be rich in exciting and emotional encouragements rather than scholarly and political instruction. It will develop Japanese soldiers' war weariness and spirit of suicide, and thus reduce the combat effectiveness of Japanese soldiers. (Editorial Team of Historical Materials of the Chinese People's Liberation Army, 1994b, p. 388)

This new strategy was arising from the new thinking and understanding about Japanese military culture and other political work of some cadres of the Party, such as Tan Zheng and Cai Qian in the Political Department of the Eighth Route Army. In the publication Military-Political Journal of The Eighth Route Army (八路軍軍政雜誌), Cai Qian pointed out that the extreme tenacity of Japanese soldiers rested on the following main reasons:

a. The political deception of Japanese imperialist education;

b. The tradition of Bushido in Japan;

c. Narrow-minded national pride;

d. Poor publicity caused by language barriers; and

e. Some Chinese comrades' misunderstood the POW policy and mistreated some Japanese POWs, which were exaggerated as a pretext of the Japanese army. (Cai, 1939, pp. 88-93) 
According to the previous analysis, it is fair to argue that despite some incomprehensive understandings, the CPC has grasped the actual situation of the war. Cai Qian, on behalf of the Eighth Route Army, also made response to the extreme thought of the Japanese military. He also came up with the strategy that the contradiction between the superior and the subordinate within the Japanese army can be utilized to enlighten class consciousness of Japanese soldiers, and add the difficulties in economic development and people's livelihood caused by the long-term war in Japan to the propaganda materials to stimulate homesickness and anti-war sentiment of Japanese soldiers. Cai also specifically stated that some feudal and superstitious ideologies commonly existed in Japanese soldiers, such as carrying the "Thousand Stitch Belt" and "Amulet" should not be criticized, because such criticism would not only hurt religious belief of Japanese soldiers and arouse their suspicions, but also impede the CPC's propaganda and transformation work (Cai, 1939).

In conclusion, the overall tendency of the new understandings and tactics was to gradually abandon the subjective impetuosity and naivety, and to be closer in line with the psychological status and actual needs of Japanese soldiers.

Some patriotic youth felt disappointed with the status quo and the future of the KMT-ruled areas, and thus came to Yan'an and joined the revolution. Some of them with either strong intention or basic Japanese language skills were selected by the CPC to receive theoretical education about Marxism and Japanese language ability. It was a strategy of the CPC to enlarge and strengthen the team of political cadres, and was undoubtedly of great significance to the CPC's work on adversaries. This essay picks a cadre of the CPC: Liu Guolin, an example of good representativeness and universality, to briefly illustrate the training system for the CPC's political cadres who participated in the work on adversaries.

Liu Guolin, originally from Shunde, Guangdong Province, graduated from Zhongkai College of Agriculture and Engineering (廣州市仲愷農工學校) in 1937. Affected by left-wing thoughts and patriotic sentiments in school, he decided to participate in the anti-Japanese work in Yan'an. He was admitted by Yan'an Anti-Japanese Military and Political University (延安抗日軍政大學) in 1938 and finished the preparatory course. Given his basic Japanese knowledge, Liu was transferred to the training class of work on adversaries at the Third Branch of the Fifth Brigade, where he further studies Japanese language and Marxist theory. At that time, two Japanese POWs, Yoshidumi Kiyoshi (吉積清, or also known as Mori Ken) ${ }^{1}$ and Haruta Yoshio (春 田好夫) were responsible for teaching Japanese language. Later, Jiang Youshu, a Chinese teacher who had studied in Japan for many years, joined them. They composed some textbooks about Japanese language, and learned Japanese grammar from some left-wing novels and scripts, as well as some anti-war songs. In order to create more opportunities for oral Japanese practice, they were required to use Japanese language as much as possible in daily communication. In 1939, Liu Guolin was officially enrolled in the CPC after graduation. He was soon sent to the Eighth Route Army Military and Political Academy (八路軍軍政學院) for further studies, where books about Marxist Theory in Japanese language were used as teaching materials for senior trainees, since their Japanese language proficiency was good enough to understand Japanese books. At the end of 1940, Liu was transported to the work on adversaries School for Cadres (敵軍工作幹部學校) as a teaching assistant for Japanese class. He also devoted himself to the foundation of Yan'an Japanese Workers and Peasants School. His superior were Wang Xuewen, head of the Department of Work on adversaries of the Central Military Commission of the CPC and the principal of the Against-Enemy Work School for Cadres, and Zhao Anbo,

\footnotetext{
${ }^{1}$ Yoshidumi Kiyoshi was his real name. But he was commonly recognized as Mori Ken, a pseudonym given to the CPC after he was captured as a POW.
} 
head of the work on adversaries Section of the Brigade 359. Liu were in touch with the JCP's leader Nosaka Sanzo (野阪參三) and other Japanese POW during his work. After Yan'an Japanese Workers and Peasants School was founded in May 1941, Liu was appointed to Taihang Anti-Japanese Base for Japanese teaching in frontline (Suzuki \& Liu, 2000).

From Liu Guolin's experience, it was not difficult to find out that the CPC had formed a completed echelon for work on adversaries by 1940. The top leaders, like the political cadres Tan Zhenghe and Cai Qian, were well-experienced in leadership, management, and theoretical attainment. Wang Xuewen and Zhao Anbo, who previously studied in Japan and served at underground intelligence or left-wing coalition of the KMT-ruled area, was in charge of teaching Japanese language and Marxist theory, as well as the direct management of POWs. Last but not least, there were newly-trained cadres, such as Liu Guolin, who either stayed in Yan'an or was transferred to anti-Japanese bases of the Eighth Route Army, to deal with the work on adversaries at the frontline. This echelon also absorbed a number of Japanese POWs who genuinely intended to surrender or had been well-transformed. However, these POWs were mainly frontline soldiers, clerks of Japanese companies in North China, and Japanese expatriates living in China. Therefore, the CPC still needed a Japanese communist to assist its work on adversaries. This person was supposed to have good theoretical knowledge and practical experience, as well as a comprehensive understanding about Japan's domestic situation and Japanese soldiers' psychology. This problem was well solved with the arrival of Nosaka Sanzo in Yan'an.

\section{Specific Practices in the Mature Period}

The period from 1940, when Nosaka Sanzo (野阪參三) arrived in China, to 1945, the year of victory of the War of Resistance against Japan, could be regarded as the mature period of the CPC's work on adversaries led by the JCP leader: Nosaka Sanzo. The Japanese People's Anti-War Alliance and the Japanese People's Liberation League were founded by a large number of Japanese POWs who finished their transformation and pledged their loyalty to the CPC. Via these associations, they participated in the work on adversaries alongside with the CPC's frontline cadres and troops in Yan'an, bases at different places, the Eighth Route Army and the New Fourth Army. Compared with the previous stage, the propaganda work to enemy and POW transformation of the CPC were remarkably enhanced, and the theoretical basis was developed to a deeper level. Such improvements helped the CPC yielded fruitful results, which not only contributed to the practice of the CPC's battlefield, but also provided the CPC with abundant experience in mobilizing a large number of Japanese POWs and colonialists in the Civil War, as well as in the handling and remolding senior POWs of the Kwantung Army and Manchukuo after the founding of the People's Republic of China. It is, to a large extent, a successful attempt in the localization of Marxist Internationalism theory by the CPC.

In 1892, Nosaka Sanzo was born in a merchant family in Yamaguchiken. The death of Kotoku Shusui (幸 德秋水), resulted from the “Outrage Incident”, nurtured his interest in socialist ideas when he was a teenager. At the age of 20, he attended Keio University where he read The Communist Manifesto (共產黨宣言), and thus embraced Marxism. After graduation, he became one of the leaders of the Friendship Association, a famous left-wing worker organization in Japan at that time. Specially assigned by the association, he went to the UK in 1919 and joined the Communist Party of Great Britain in the same year. Later, he was expelled by the British government for participating in the left-wing labor movement and returned to Japan in 1922, and participated in the establishment of the JCP. In the same year, Nosaka Sanzo joined the JCP, becoming one of its early leaders. He was arrested and imprisoned in 1923 and 1928 respectively, but he persisted in the revolutionary work in 
prison and was released in 1930 for eye diseases. He was elected as a member of the Central Committee of the JCP in 1931 and later traveled to Moscow as a representative of the JCP in the Communist International. In 1933, after Sen Katayama's death, Nosaka Sanzo inherited his duty and served as a standing committee member of the executive committee of the JCP. In 1940, because the normal repatriation channel to Japan was blocked due to the War, George Dimitrov ${ }^{2}$ agreed the CPC to escort Nosaka Sanzo to Yan'an first, where he may find another way to Japan.

Nosaka Sanzo was warmly welcomed in the manner of Central Committee-Level in Yan'an by the CPC. However, after a thorough consideration, the CPC rejected his return plan, because it was impossible to return to Japan by getting across the Japanese military's blockade line. At that time the blockade line was no different from jaws of death. Therefore, the CPC advised Nosaka Sanzo to temporarily wait in Yan'an for a positive situation. He had no options but to accept the CPC's arrangements and began to lead the political work towards Japanese military. First, he took over the Japan Problem Research Institute of the CPC, since the leaders of the Party were not satisfied with its previous achievements. Because Nosaka Sanzo's identity was confidential, he published a series of articles in the name of Wang Xuewen, the minister of the work on adversaries department who was responsible for the liaison and communication work with the CPC. Edited and distributed by the Political Department of the Eighth Route Army, these articles analyzed Japanese political, economic, and military conditions comprehensively, and thus caused a certain degree of repercussions within the CPC. In addition, with the help of Wang Jiaxiang, the director of the Political Department, Nosaka Sanzo and other political cadres of the Eighth Route Army collected a great quantity of Japanese newspapers, magazines, and other publications to conduct studies on the work on adversaries. They also listened to Japanese radios to understand the real-time political dynamic of Japan (Nosaka, 1963, pp. 203-205).

With certain achievements in the research on Japan, Nosaka Sanzo proposed to Wang Xuewen whether a school could be established in Yan'an to concentrate a few hundred selected Japanese POWs for democracy education. It would not only help the conduction of propaganda activities at that time, but also be of vital importance for post-war democracy realization in Japan. This proposal was promptly approved by the leaders of the CPC. As a result, Nosaka Sanzo was transferred by the CPC to a place closer to the Political Department of the Eighth Route Army to prepare the establishment of Yan'an Japanese Workers and Peasants School together with Wang Xuewen.

In the summer of 1940, Nosaka Sanzo held discussions with political cadres who were involved in work on adversaries, including Zhao Anbo and Li Chuli, regarding the tenet and general principles of Yan'an Japanese Workers and Peasants School. Ultimately, nine general rules were formulated:

Article 1 The School should be named Yan'an Japanese Workers and Peasants School;

Article 2 The main purpose of the School was to conduct political education to Japanese soldiers;

Article 3 The teaching subjects of the School should be: Politics, Economics, Japanese Research, Chinese, Current Affairs, and others as required;

Article 4 The term of study at the School shall be one year;

Article 5 Students shall be allowed to enter the School only after being examined and recommended by the student review committee and signing the application for admission. The relevant student code would be noticed later;

${ }^{2}$ Georgi Dimitrov, also known as Georgi Mikhaylovich Dimitrov, was a Bulgarian communist dictator. He was appointed General Secretary of the Comintern from 1934 until the organization's dissolution in 1943. 
Article 6 The School is affiliated to the Political Department of the Eighth Route Army, which shall appoint five members to form the school council. The School council has the final-decision-making power on the administration;

Article 7 The Political Department of the Eighth Route Army shall appoint the principal, deputy principals, provosts, and deans of student affairs. The principal shall administer school affairs; deputy principals shall assist the principal or supervises the school administration on behalf of the principal;

Article 8 The council is entitled to establish student review committees, education committees, economic committees, and other committees as necessary. The membership and composition of the concerned committees will be determined separately; and

Article 9 Students are entitled to enjoy the necessary convenience and guarantees for study and life; should obey the regulations of the School, any violation may result in expulsion; should be engaged in certain production while studying.

Students have the right to organize student union to conduct autonomy consultations on the improvement of study, discipline, health care, entertainment, and other issues, and then make recommendations to the School authorities (Mizuno, 1983, p. 188).

From the above articles, it is not difficult to conclude that Yan'an Japanese Workers and Peasants School aimed at absorbing the possible Japanese POWs detained by the CPC and military affiliates via ideological indoctrination and other ideological education. They were supposed to be cultivated as Japanese cadres who not only participated in and assist with the Eighth Route Army in work on adversaries in their free will, but also understood that their efforts in the War of Resistance against Japan would ultimately contribute to the fulfillment of the CPC's revolutionary idea about creating a red Japan in the future. After discussions, the top leaders of the CPC agreed on the nine general rules. They relocated a cadre-training school in the vicinity of Pagoda Mountain (a famous landmark in Yan'an), so that some caves and sites were ready to use for Yan'an Japanese Workers and Peasants School. Nosaka Sanzo was appointed as the principal of the school in the name of Lin Zhe, with Li Chuli and Zhao Anbo served as deputy principals. With 11 Japanese trainees' arrival at Yan'an, the School was officially operated in October 1940. In March 1941, another 14 students arrived at Yan'an from Shandong Base, making the number of students in the school grow to 25 (Sun, 1996, p. 175).

After more than six months' personnel deployment and infrastructure construction, the opening ceremony for the first batch of students at Yan'an Japanese Workers and Peasants School was held in the Eighth Route Army Grand Auditorium in Yan'an on May 15, 1941. Zhu De (commander-in-chief of the Eighth Route Army), Fu Zhong (deputy director of the General Political Department), Feng Wenbin (a key member of the Northwest Youth National Salvation Association), and over 2,000 people from the central government, different schools, and civil groups of Yan'an, all participated in the ceremony. Besides, Mao Zedong wrote an inscription for the school in person: "Chinese people are consistent with Japanese people, we are fighting against the same enemy: Japanese imperialists and Chinese scums" (Kobayashi, 1985, pp. 92-93).

Meanwhile, the School received numerous telegrams of warm congratulations from anti-Japanese bases and Japanese anti-war groups of the KMT areas. Sugimoto Kazuo (杉本一夫), Sakata Taro (阪田太郎), Takagi Toshio (高木敏雄), and Matsui Hideo (松井英男) felicitated and spoke highly of the establishment of the School on behalf of the Japanese People's Awakening Alliance. They argued that it was 
a pioneering initiative that has never existed before; a brand new page in the history of people's liberation in the East; and a banner for Chinese people and Japanese people to march hand in hand against our common enemy: Japanese imperialists. (Sun, 1996, p. 175)

Students stood on the podium to express their gratitude to the CPC, its leaders, the Eighth Route Army, and representatives from various sectors in Yan'an. They solemnly swore to the CPC and all the Eighth Route Army officers under the witness of the participants.

Esteemed Officers and Soldiers of the Eighth Route Army,

We have just taken the first step on the road to rebirth. Our life relies on the support and guidance of our beloved comrades, who are willing to offer more edification and assistance in the future.

We give sincerely appreciations to leaders of the CPC and the Eighth Route Army for their guidance, as well as to the schools and civil groups for their kind encouragement. We are determined to work hard at school and will promise to live up to the expectations of our comrades.

Finally, our highest gratitude goes to the CPC and the leaders of the Eighth Route Army. We'd like to express our sincere gratitude for the care and guidance in setting up our school and managing the teaching affairs.

Once again, we shall fight to the end to achieve our vows!

Overthrow Japanese imperialism!

Long live the joint struggle of Chinese and Japanese compatriots! (Mizuno, 1983, pp. 191-192)

Students' oaths won thunderous cheers and applause. During the grand evening party, participants from both China and Japan presented a variety of art performances, among which the most popular show was the drama: Outpost. Played by Japanese students, it reflected the proletarian thoughts. On the next day, students organized a seminar to discuss their theoretical progress and ideological changes since arrival, as well as their expectations and requirements for study and work in the future (Kobayashi, 1985, pp. 97-99).

Since then, Yan'an Japanese Workers and Peasants School has become increasingly formalized. After the dissolution of the Communist International in 1943, Nosaka Sanzo resumed his old alias: "Okano Susumu (岡 野進)", and began to exercise the formal leadership of Yan'an Japanese Workers and Peasants School and some Japanese people's anti-war organizations, such as Japanese People's Anti-War Alliance, Japanese People's Communist Alliance in China, and Japanese People's Liberation League. The amount of students of the School also increased gradually. By May 15, 1944, the School had 69 regular students, consisting of 15.9\% farmers, $13.1 \%$ clerks, $5.8 \%$ businessmen, $56.5 \%$ workers, and $1.5 \%$ fishermen. Only three of them had a college or equivalent certificate, while $80 \%$ students' education degree was below secondary school (Kobayashi, 1987, pp. 51-52).

According to Kagawa Takashi (香川孝志), a teacher of the School, from the beginning of the full-scale Anti-Japanese War in 1937 to May 1944, among 2,407 Japanese POWs of the Eighth Route Army and 115 Japanese surrendered Japanese soldiers, about 300 had studied in Yan'an Japanese Workers and Peasants School. The number of the students was changed from time to time as some students graduated and joined the work on adversaries of the CPC. By August 1945 when Japan fully surrendered, the number of Japanese students was over 250 (Kobayashi, 1987, p. 103).

By recalling the research on POW's treatment during the Second World War in the introduction part, it was clear that, although the Geneva Convention (日內瓦公約) and the Hague Convention (海牙公約) had 
stipulated a series of treaties concerning the proper treatment of POW (such as a POW should be treated equally in terms of food, accommodation, and clothing to the troops of the government that captured them), the main belligerent countries other than the United States failed to comply with this requirement in the Second World War. However, while the CPC did not sign the two Conventions above, and thus was not obliged to abide by the relevant provisions, preferential treatment was granted to Japanese POWs and their dependents, which far exceeded the standards of treatment for its own soldiers. After Maeda Mitsushige (前田光繁) was captured, he was supplied with rice, steamed breads, and noodles as staple food and subsidized with pork, eggs, and vegetables. On the contrary, soldiers of the Eighth Route Army who were in charge of him relied on millet and wild herbs. Another example was Sato Takeo (佐藤猛夫), who was favorably treated with adzuki bean soup with rice cake (a traditional Japanese food made from brown sugar). In those years, brown sugar was extremely rare, and had to be specifically purchased by the Eighth Route Army.

There were roughly two reasons why the CPC adopted such a strategy. Firstly, after the Sanwan Reorganization (三灣改編), the CPC attached great importance to political propaganda and ideological construction inside the army. According to the Marxist class view, the Japanese soldiers were not the real enemies, but class siblings hoodwinked by the ruling class of Japan. Therefore, treating ordinary Japanese POWs with empressement was in accord with the ideological requirements of the $\mathrm{CPC}$, and thus was stipulated in the military discipline of the Eighth Route Army. Secondly, from the standpoint of struggle strategies, the CPC put psychological blow and disintegration in the same league as a physical attack. A favorable treatment to POW may not help the actual battle, but it was beneficial for the CPC's propaganda work, eradicating the misleading stereotype that "the Eighth Route Army maltreated and massacred POWs" maintained by Japan. Such strategy not only undermined the fighting morale and fighting will of Japanese front-line forces, but also eliminated the vigilance of Japanese POWs and persuaded them to acknowledge the CPC fronts. Hence, the policy of preferential treatment towards POWs played an important role in the Eighth Route Army's work on adversaries. In September 1941, the General Political Department of the Eighth Route Army issued the Provisions on Preferential Treatment of Japanese POWs (關於日本戰俘優待辦法的規定). It stipulated that the catering expenses of POWs should be twice than that of soldiers of the Eighth Route Army; POWs shall dine together on main Japanese celebrations; some flour and rice should be allocated to POWs by the food supply organ, etc.

The policy was strictly executed in Yan'an, where materials and resources were relatively adequate. The preferential treatment received by students in Yan'an Japanese Workers and Peasants School was far better than that of common Japanese POWs or even the general Eighth Route Army commanders during the War of Resistance against Japan. It was stipulated in the Methods of Preferential Treatment Towards Japanese Students in Yan'an by the General Political Department of the Eighth Route Army (八路軍總政治部優待在延 日本學生辦法) of Decision on the Education and Work of Yan'an Japanese Workers and Peasants School (關 於延安日本工農學校教育及工作的決定) (issued by the General Political Department of the Eighth Route Army).

Students in Yan'an Japanese Workers and Peasants School were treated as company-level cadres, who shall be provided with a monthly allowance of three yuan. At that time, a cadre at or above the division level, including Mao Zedong and Zhu De, could only receive five yuan per month as allowance. Moreover, students were supplied with special provisions, including: (1) $500 \mathrm{~g}$ pork per month per person; (2) an additional $5 \mathrm{~kg}$ 
refined flour for each person per month besides the provisionment; and (3) for the New Year, important festivals, or Japanese celebrations, special dining fees would be approved upon request. Newcomers were offered with (a) an allowance of five yuan in the first month; (b) quilt and felt would be supplemented in accordance with the actual need; (c) one pair of shoes and socks; (d) one towel and a bar of soap per capita; (e) a toothbrush; (f) a pack of tooth powder and a packet of cigarettes; (g) a tobacco pipe; (h) a bowl and a pair of chopsticks; (i) a vest and a pair of pants; and (j) a shirt and a pair of trousers. Besides, every four months, each student was supplemented with: (1) a pair of shoes and socks; (2) a toothbrush; (3) one towel; (4) two pieces of soap; and (5) $1 \mathrm{~kg}$ tobacco (General Political Department of the Eighth Route Army, 1941; Kobayashi, 1987, p. 56). At that time in Yan'an, $500 \mathrm{~g}$ pork was only half yuan, and a large bowl of pork noodles was 0.13 yuan. On Sundays, students would go to the street in groups and spent their allowances on wine or a big bowl of pork noodles (Kagawa \& Maeda, 1985, p. 56).

When Yan'an Japanese Workers and Peasants School was firstly established, the food of the School mainly included rice and flour, together with a variety of vegetables, eggs, meat, and weekly-served dumplings (Kobayashi, 1985, p. 88). Since 1940, the border of Shanxi-Gansu-Ningxia region suffered from not only natural disasters in Northwest China, but also the military encirclement and economic blockade initiated by the diehards of the KMT, as well as the brutal "mopping-up" launched by Japanese army after the Hundred-Regiment Campaign. All these difficulties hugely challenged the fiscal economics, people's livelihood, and the food supply around the border of Shaanxi-Gansu-Ningxia region. With the skyrocketing prices in Yan'an, the lives of Japanese students in the School were also affected. Their staple food changed from rice and steamed bread to millet. In such a difficult situation, the CPC still attempted to guarantee the daily necessities for Japanese students to the greatest extent. Understanding the difficulties of other comrades, students proactively suggested "no meat for breakfast and less meat for dinner", and apply for participating in the great production campaign to ease the burden on the CPC and the local government. Their application was approved by the CPC in the condition that their studies shall not be influenced. Henceforth, students pitched into the production by making the most of the morning exercise time, lunch breaks, free time after dinner and Sundays. They reclaimed a total of $70 \mathrm{mu}$ of wasteland and by the fall of 1943 , they harvested 5,000 $\mathrm{kg}$ potatoes and 9,000 $\mathrm{kg}$ soybeans and corn. The crops were purchased by the cooking team and the local government, which enabled the school to set up co-operations. By 1944, every student had some savings and their average investment to the cooperation reached more than 3,000 yuan (Wang, 1989, p. 262).

On August 15, 1945, Japan announced its surrender. Yan'an Japanese Workers and Peasants School, which had operated for more than four years, successfully fulfilled its political mission. The students, while celebrated the long-awaited victory, also fretfully prepared their returns to Japan. Most students intended to donate their deposits during study to the SAR government, but the CPC declined their kindness. On August 30, 1945, the CPC arranged a farewell ceremony at Wangjiaping Auditorium for these Japanese students. Ye Jianying, the chief of staff of the Eighth Route Army, as well as the government officials who had been living with these students for over four years, attended the ceremony. Ye Jianying deemed that,

a few years ago, we welcomed you as friends come from afar, and today, we are here to say goodbye to you all, my dear friends. Our friendships shall last forever! Comrades, we must further develop the precious relationship between Chinese and Japanese people! (Kagawa \& Maeda, 1985, pp. 105-108) 
He also expressed his sincere wishes for a democratic Japan, that "peace and democracy will come to Asia should a democratic China and a democratic Japan join each other hand in hand" (Kagawa \& Maeda, 1985, pp. 105-108).

Yan'an Japanese Workers and Peasants School, the Japanese People's Liberation League, and the Japanese People's Communist Alliance in China jointly paid their gratitude to Chairman Mao Zedong and Commander in Chief Zhu De via a telegram. They said

with the aid of the CPC, we are heading to a glorious future! With new expectations, we are returning to our motherland. The Sino-Japanese relationships will be promoted to a new stage where a mutual-beneficial friendship shall replace wars and aggressions. Such relationship relies on the establishment of a peaceful and democratic Japan, on the efforts of Japanese people. Many difficulties are in the front, but we are under firm belief that all difficulties will be overcome until we achieve the final victory. The solidarity of Japanese people lasts forever. (Kagawa \& Maeda, 1985, pp. 105-108)

Before attending the negotiation between the CPC and the KMT in Chongqing, Zhou Enlai took some time to visit Japanese students in Yan'an Japanese Workers and Peasants School. He said,

Congratulations on your returning home. Please forgive us for not preparing precious sendoff gifts. However, the people we are sending back to Japan are promising youngsters for the construction of a new Japan. I believe you are the most valuable gifts from us to Japan. (Kagawa \& Maeda, 1985, pp. 105-108)

In mid-September, more than 200 anti-war Japanese people (most of them were students in Yan'an Japanese Workers and Peasants School) departure from Yan'an. They walked ahead to Northeast China, intending to back home through North Korea.

\section{Summary}

This article summarized the CPC's work on adversaries during the War of Resistance against Japan. At that time, the theoretical basis for the CPC was Marxist Internationalism that low rank officials and soldiers fighting in the Japanese army were not the enemies but class siblings and victims of the war. They were blinded and deceived by the Japanese ruling class and were forced to leave homes and fight against Chinese people. The CPC hoped to transform them with Marxist world outlook and values, so that they could become the CPC's allies in the war, as well as a backbone force of a "Red Japan" in the future.

Although the ideological basis was followed throughout the war, the specific practice of the CPC's work on adversaries could roughly be divided into two phases. The first phase, from 1937 (when the CPC fully joined the War of Resistance against Japan) to 1940, was regarded as the exploration stage. At this stage, the principles of propaganda and transformation previously used to the KMT POWs during the Agrarian Revolution were basically followed. However, the effectiveness was far from expectation. Combined with the new experience gained from the War of Resistance against Japan, the CPC re-evaluated its propaganda tactics and strategies, promoting the participation of Japanese people in its work on adversaries. Because of the realistic condition, the CPC failed to transform Japanese POWs thoroughly, but returned POWs after a short-term preferential treatment.

The second stage started from 1940 and ended with the War in 1945. In this period, the JPC leader, Nosaka Sanzo, who had abundant theoretical knowledge and practical experience in actual struggles, arrived at Yan'an and began to take part in the CPC's work on adversaries. The participation of Nosaka Sanzo, together with some optimistic changes, such as the power reversal of both sides and the strengthening of the $\mathrm{CPC}$, made it possible 
for the CPC to initiate ideological indoctrination and transformation of Japanese POW in a large scale. Some activists were later absorbed to the anti-war organizations led by the CPC and the Communist Alliance. These activists were familiar with Japanese culture, mental status of Japanese army, and actual conditions of the Japanese military, which helped the CPC form a set of propaganda strategy for its work on adversaries, as well as a management system which not only was effective in instilling Japanese POWs with Marxism, but also mobilized them to participate in the War of Resistance against Japan and the future creation of a "Red Japan". During this period, positive results were achieved by the CPC regarding its work on adversaries, such as the development and establishment of Yan'an Japanese Workers and Peasants School and some anti-war organizations (represented by the Anti-War Alliance and the Liberation League). The experience of the CPC in adopting Japanese POWs as a backbone force in the work on adversaries during the War of Resistance against Japan was remarkable and referable. During the Civil War, the CPC recruited a massive number of previous Japanese POWs and colonialists. After the founding of the PRC, the CPC also referred to its previous experience to undertake the transformation and management of the KMT POWs and senior officers of Manchukuo POWs. It is fair to argue it as a successful attempt to localize Marxist Internationalism theory in China.

Objectively speaking, the CPC's work on adversaries can be recognized as a wonder under the foot of Pagoda Mountain in Yan'an. Undoubtedly, compared with other major forces in the battlefields of the Second World War in China, the CPC was relatively weak. It had the least resources that could be invested in the management and transformation of POWs, while the Japanese army was famous for their tenacity and stubbornness in fighting. However, under such extremely poor conditions, the CPC achieved considerable transformation results, reaching a higher rate of conversion. According to the data in 1944, among 2,407 POWs captured by the Eighth Route Army and 115 Japanese willing-surrenders, approximately 300 people studied at Yan'an Japanese Workers and Peasants School, and 223 people joined the Anti-War Alliance. Almost all POWs who had been under transformation over one year joined the CPC's anti-war operations, and a large number of them sacrificed on the battlefield for the Chinese and Japanese liberation, among whom 38 had their names left (Kobayashi, 1987, p. 132).

After returning to Japan, a great number of these Japanese "Eighth Route Army soldiers" persisted in their communist belief regardless of the huge pressure from Japanese government and public opinion. They founded the Eighth-Fourth League (八四會, which takes the character "Eight" of the Eighth Route Army and the character "Fourth" of the New Fourth Army respectively) to organize regular campaigns, publish related materials, write memoirs, and spread words about their experiences in China and the atrocities committed by Japanese soldiers in the war they had witnessed, turning a deaf ear to the police's surveillance and interference. Besides, after the normalization of diplomatic ties between China and Japan, they also returned to China a great number of times to strengthen the friendship between two countries.

\section{References}

Akiyama, Y. 秋山良照 (1977). Chugoku Tochi Kaikaku Taikenki 中國土地改革體験記 [Experience of national land reform in China]. Tokyo: Chuo Koronsha.

Akiyama, Y. 秋山良照 (1978). Chugoku Sensen no Hansen Heishi: Senso to Ningen no Kiroku 中国戦線の反戦兵士一戦争と 人間の記録 [The anti-war soldiers: The records of war and life]. Tokyo: Gendaishi Shuppankai.

Bao, H. S. 鮑惠蘇 (2007). Kangri zhanzheng shiqi Zhongguo Gongchandang de rijun fulu zhengce yanjiu 抗日戰爭時期中國 共產黨的日軍俘虜政策研究 [The research on the CPC's policy to Japanese POWs during the War of Resistance against Japan] (MA thesis, Huadong Normal University). 
Bertram, J. 貝特蘭 (1986). North China front 華北前線. (D. Q. Lin 林淡秋, Trans.). Beijing: Xinhua chubanshe.

Cai, Q. 蔡前 (1938). Zenyang jinxing dijun gongzuo 怎樣進行敵軍工作 [How to engage work for the enemy]. Qunzhong, 12, 220.

Cai, Q. 蔡前 (1939). Riben jundui de zhengzhi texing 日本軍隊的政治特性 [The political traits of the Japanese army]. Balujun junzheng zazhi 八路軍軍政雜誌, 1(8), 88-93.

Editorial Team of Historical Materials of the Chinese People's Liberation Army 解放军历史资料丛书编审委员会编. (Ed.). (1994a). Balujun zhengzhibu guanyu kaizhan rijun zhengzhi gongzuo de zhishi 八路軍政治部關於開展日軍政治工作的指 示 [The instructions of Political Department of the Eighth Route Army on the political work towards the Japanese army]. Balujun wenxian 八路軍文獻 [Archives of the Eighth Route Army]. Beijing: Jiefangjun chubanshe.

Editorial Team of Historical Materials of the Chinese People's Liberation Army 解放军历史资料丛书编审委员会编. (Ed.). (1994b). Zhonggong zhongyang junwei zhengzhibu guanyu riweijun gongzuo de xunling 中共中央軍委總政治部關於日偽 軍工作的訓令 [The directive order from the General Political Department of the Central Military Commission of the Communist Party of China on the work against the Japanese army and its puppet army]. Balujun wenxian 八路軍文獻 [Archives of the Eighth Route Army]. Beijing: Jiefangjun chubanshe.

Gao, H. 高華 (2000). Hongtaiyang shi zenyang shengqi de: Yan'an zhengfeng yundong de lailong qumai 紅太陽是怎樣升起 的: 延安整風運動的來龍去脈 [How does the red sun rise: The origin of the Yan'an rectification movement]. Hong Kong: Chinese University Press.

General Political Department of the Eighth Route Army 八路軍總政治部. (1941). Balujun zong zhengzhibu youdai zaiyan riben xuesheng banfa 八路軍總政治部優待在延日本學生辦法 [Methods of preferential treatment towards Japanese students in Yan'an by the General Political Department of the Eighth Route Army].

Imamura, K. 今村匡平 (1967). Akai Hoshi no Shita de-Kaihoguni Ryuyo 8nen no Kiroku 赤い星の下で一解放軍々医留用8 年の記録 [Under the red star: 8-year record of an medical officer of the People’s Liberation Army]. Nagano-shi: Shinmai Shoseki Shuppanbu.

Jia, B. B. 賈蓓蓓 (2001). Kangri zhanzheng shiqi jiefangqu de Ribenren fazhan yundong 抗日戰爭時期解放區的日本人反戰 運動 [The Japanese anti-war activity in liberation area during the War of Resistance against Japan] (MA thesis, Yanan University).

Kagawa, T., 香川孝志 \& Maeda, M. 前田光繁 (1984). Hachirogun no Nihonhei tachi: Enan Nihon Rono Gakko no Kiroku 八 路軍の日本兵たち一延安日本労農学校の記録 [The Japanese soldiers in the Eighth Route Army: The record of the Yanan Japanese Worker And Peasant School]. Tokyo: Saimaru Shuppankai.

Kagawa, T., 香川孝志 \& Maeda, M. 前田光繁 (1985). Balujun nei Ribenbing 八路軍內日本兵 [The Japanese soldiers in the Eighth Route Army]. (A. B. Zhao 赵安博, Trans.). Beijing: Jiefangjun chubanshe.

Kobayashi, K. 小林清 (1985). Zai Zhongguo de tudi shang: yige Ribenbalu de zishu 在中國的土地上一一個日本八路的自述 [On the land of China: Self-statement of a Japanese Eighth Route Army soldier]. Beijing: Jiefangjun chubanshe.

Kobayashi, K. 小林清 (1987). ZaiHua riren fanzhan zuzhi shihua 在華日人反戰組織史話 [The history of Japanese anti-war organizations in China]. Beijing: Shehui kexue wenxian chubanshe.

Literature Research Office of the Central Committee of the Communist Party of China 中共中央文獻研究室編. (Ed.). (1991). Balujun gao riben shibing shu 八路軍告日本士兵書 [The Eighth Route Army's letter to Japanese soldiers]. Zhonggong zhongyang dangan xuanji (Di shiyi ce) 中共中央檔案選集: 第十一冊 [Selected archives of the Central Committee of the Communist Party of China]. Beijing: Zhonggong zhongyang dangxiao chubanshe.

Luo, R. Q. 羅瑞卿 (1988). Dui dijun de zhengzhi gongzuo 對敵軍的政治工作 [Political work on adversaries]. Zhongguo renmin jiefangjun lishi ziliao congshu balujun huiyi shiliao 中國人民解放軍歷史資料叢書一八路軍回憶史料 [History of the Chinese People's Liberation Army: Historical materials of the Eighth Route Army memories. (Editorial Team of Historical Materials of the Chinese People's Liberation Army, Ed.). Beijing: Jiefangjun chubanshe.

Mao, Z. D. 毛澤東 (1991). Mao Zedong xuanji (Juan er) 毛澤東選集（卷二） [Selected works of Mao Zedong (Vol. 2)]. Beijing: Renmin wenxue chubanshe.

Marx, K., \& Engels, F. (1848). The Communist Manifesto. 
Mizuno, Y. 水野靖夫 (1974). Nihongun to tatakatta Nihonhei: Wagawakakihi no Ikigai 日本軍と戦つた日本兵一わが若き 日の生きがい[The Japanese soldiers fight against Japanese army: The life meaning of our youth]. Kitakyūshū shi: Shiraishi Shoten.

Mizuno, Y. 水野靖夫 (1983). Fanzhan bingshi shouji 反戰兵士手記 [The hand record of the anti-war soldiers]. (C. J. Gong 腪長金, Trans.). Beijing: Jiefangjun chubanshe.

Nihon Kyosanto, Chuoiinkai Hansen, Domei Kiroku \& Henshu Iinkai 日本共産党中央委員会反戦同盟記録編集委員会. (1963). Hansen Heishi Monogatari-Zaika Nihonjin Hansen Domeiin no Kiroku 反戦兵士物語一在華日本人反戦同盟員 の記録 [The story of anti-war soldiers: The record of members of Japanese Anti-War Alliances in China]. Tokyo: Nihon Kyosanto Chuoiinkai Shuppanbu.

Nihon Kyosanto, Chuoiinkai Hansen, Domei Kiroku \& Henshu Iinkai 日本共産党中央委員会反戦同盟記録編集委員会. (1987). Cong diguo junren dao fanzhan yongshi 從帝國軍人到反戰勇士 [From imperial soldiers to anti-war warriors]. (Editorial Board of Memoirs of Members of Japanese Anti-War Coalition 日本反戰同盟成員回憶錄編輯委員會編, Ed., H. C. Zhang 張惠才 \& F. Q. Han 韓鳳琴, Trans.). Beijing: Zhongguo wenshi chubanshe.

Nosaka, S. 野阪參三 (1963). Yan'an huiyi 延安回憶 [Yan'an memories]. Yebancansan xuanji zhanshipian 野阪參三選集 (戰 時篇） [Selected works of Nosaka Sanzo (Wartime literature)]. Beijing: Renmin chubanshe.

Sun, J. K. 孫金科 (1996). Riben renmin de fanzhan douzheng 日本人民的反戰鬥爭 [The anti-war activity of Japanese people]. Beijing: Beijing chubanshe.

Suzuki, D., 鈴木傳三郎 \& Liu, G. L. 劉國霖 (2000). Yige laobalu he riben fulu de huiyi 一個老八路和日本俘虜的回憶 [Memoir of a former member of the Eighth Route Army and a Japanese prisoners of war]. (G. L. Liu 劉國霖, Trans.). Beijing: Xueyuan chubanshe.

Wang, T. Y. 王庭岳 (1989). Zaihua riren fanzhan yundong shilue 在華日人反戰運動史略 [The history of Japanese anti-war activity in China]. Zhengzhou: He'nan renmin chubanshe.

Yamaguchi, M. 山口盈文 (1994). Boku wa Hachirogun no Shonenhei datta 僕は八路軍の少年兵だった [I was a young soldier of the Eighth Route Army]. Tokyo: Soshisha.

Yang, H. L. 楊海亮 (2013). Balujun duidi gongzuo bianhua shuxi 八路軍對敵工作變化述析 [The analysis of work on adversaries of the Eighth Route Army]. Yan'an daxue xuebao shehui kexue ban 延安大學學報社會科學版, 35(4), 18-26. 